\title{
Santa Giusta Lagoon (Sardinia): phytoplankton and nutrients before and after waste water diversion
}

\author{
Nicola SECHI*, Fatima FIOCCA, Antonietta SANNIO and Antonella LUGLIÈ \\ Department of Botany and Plant Ecology, University of Sassari, Via Muroni 25 - 07100 Sassari, Italy \\ *e-mail corresponding author: sechi@ssmain.uniss.it
}

\begin{abstract}
The purpose of this paper was to assess the effect of the diversion of waste water on the trophic status of the Stagno di Santa Giusta, a hypertrophic lagoon on the centre-western coast of Sardinia. The data available (1990, 1992-1994) before the diversion (1995) were compared with those collected from 1995 to 1999. The lagoon has an area of about $8 \mathrm{~km}^{2}$; its mean depth is about $1 \mathrm{~m}$ and is well mixed as regards circulation and stratification. This study examined temperature, salinity, pH, main nutrients (reactive and total phosphorus, nitrate and ammonium nitrogen, reactive silica), chlorophyll-a, phytoplanktonic density and phytobenthic biomass. A comparison of the condition of the water before and after the diversion showed that there was an insufficient reduction in nutrient concentrations. The mean concentrations of nitrate nitrogen and ammonium nitrogen fell from 33 and $87 \mathrm{mg} \mathrm{N} \mathrm{m}^{-3}$, respec-

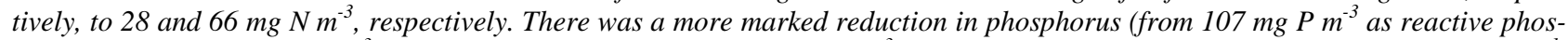
phorus and from $190 \mathrm{mg} \mathrm{P} \mathrm{m}^{-3}$ as total phosphorus to 77 and $127 \mathrm{mg} \mathrm{P} \mathrm{m}^{-3}$, respectively), and in reactive silica, from 3 to $1.7 \mathrm{mg} \mathrm{l} l^{-1}$. Chlorophyll-a decreased from 11.3 to $10.2 \mathrm{mg} \mathrm{m}^{-3}$; the total density of phytoplankton dropped considerably, but this was due to a different species composition. Phytobenthic biomass showed no particular variations. There were no changes in trophic level, so that dystrophic crises still occurred after the diversion. The results showed that there were no substantial improvements in the trophic status of the lagoon during the years after the diversion, except for some months in 1995. A possible explanation may lie in the structure of the diversion system, which does not completely stop the inflow of sewage into the lagoon.
\end{abstract}

Key words: coastal lagoons, eutrophication, Sardinian lagoons, long-term monitoring, waste diversion

\section{INTRODUCTION}

The lagoons of Sardinia make up about $2.6 \%$ of all the lagoons in Italy. They extend over about $100 \mathrm{~km}^{2}$ (Cottiglia 1981) and many of them are included in the Ramsar convention (protection of wetlands), drawn up in 1971.

One of the most important, both from a naturalistic and an economic point of view, is the Stagno di Santa Giusta, a sub-tropical lagoon with the dry/wet seasons typical of the Mediterranean region (Fig. 1). The lagoon is almost circular and choked, it has an area of about 8 $\mathrm{km}^{2}$ and a mean depth of about $1 \mathrm{~m}$, and is well mixed as regards circulation and stratification. A coastal sandbar divides the lagoon from the sea. There was originally a connection with the sea through the outlet of the River Tirso, via a channel (Pesaria Channel) about $3 \mathrm{~km}$ long, which permitted the only freshwater inflows in the wet period and the only seawater inflows in the dry period. In 1958, the channel was deepened (3 m), widened $(6 \mathrm{~m})$, separated from the river and connected directly with the sea.

In 1970, some canals $2 \mathrm{~m}$ deep and $6 \mathrm{~m}$ wide starting from the opening of the Pesaria Channel were bored so that the seawater could reach every part of the lagoon. At the same time, during the construction of an industrial harbour (Fig. 1), an industrial canal communicating with the sea was built. In addition, a fish catch system (bordigue) was built half-way down the Pesaria Channel, causing a considerable reduction in depth and width, with repercussions on the tide exchange volume.

Fish production was always high (above $500 \mathrm{~kg} \mathrm{ha}^{-1}$ $\mathrm{y}^{-1}$ ) (Rossi \& Cannas 1992), reaching peaks of about $800 \mathrm{~kg} \mathrm{ha}^{-1} \mathrm{y}^{-1}$ in 1977; this was probably due to the high trophic level. In fact, the hypertrophic status of the lagoon (Sechi 1982, 1983) was in agreement with the high availability of nutrients, especially phosphorus.

During the following ten-year period, fish production progressively decreased, and in September 1989 a dystrophic crisis characterised by total deoxygenation of the water caused the mortality of the whole animal component in the lagoon. During the following years, production was always lower than $100 \mathrm{~kg} \mathrm{ha}^{-1} \mathrm{y}^{-1}$ and was sometimes completely absent due to further dystrophic episodes, which caused total or partial fish mortality. The decrease in fishing and the increase in dystrophic episodes may be related to a further raising of the trophic level, due to an increase in the population (also in the number of people connected to the drainage system) and in industrial activities during this period. The total number of inhabitants rose to 45,000 .

The phosphorus load was measured on the basis of this number of inhabitants. It was about $40 \mathrm{t} \mathrm{y}^{-1}$ in 1989 , a value much higher than would be roughly necessary (4 $\mathrm{t}^{-1}$ ) to keep phosphorus concentrations lower than 20 $\mathrm{mg} \mathrm{P} \mathrm{m}{ }^{-3}$, assuming a bimonthly water exchange due to an inflow of $170 \times 10^{6} \mathrm{~m}^{3}$, of which 30 were freshwater. 


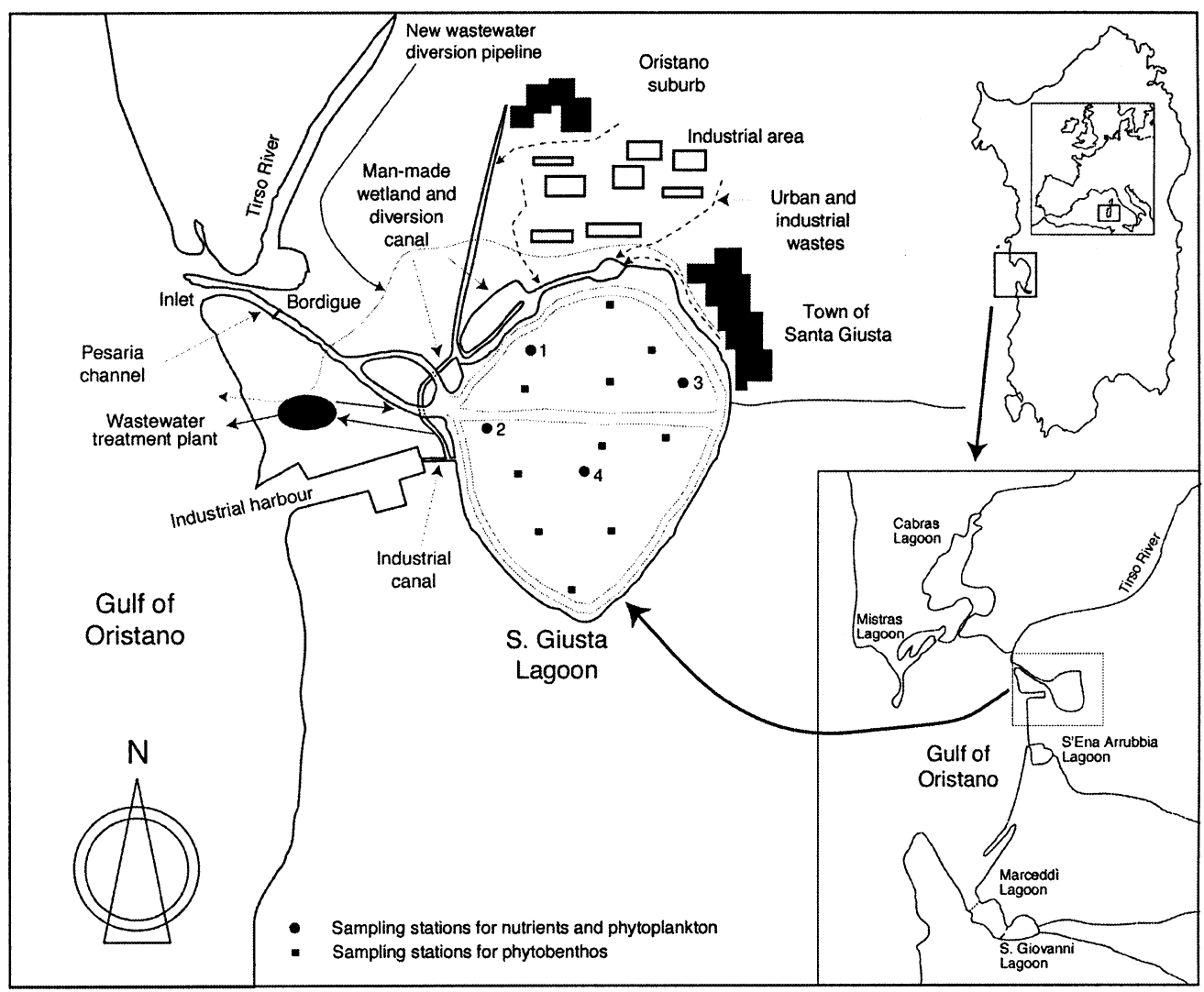

Fig. 1. Santa Giusta Lagoon, diversion system of wastes and sampling stations.

These values (calculated by Sechi in 1990 in a technical report) were only a rough estimate, but the Regional Government of Sardinia judged them sufficient to plan a diversion of urban wastes. The structure was built in 1995 and consists of a surrounding canal collecting the wastes of Oristano and Santa Giusta (Fig. 1). Its considerable size makes it a freshwater wetland system, extending over the north-eastern area, crossing it parallel to and close to the coast of the lagoon. It was designed to operate as a biological nutrients removal system; so partially treated waters, after a distance of some $\mathrm{km}$, would be channelled to a sewage treatment plant, collected in one canal, and then discharged into the industrial canal. They could also be discharged directly into the lagoon, but this operation had to be performed under control.

From November 1998 to July 1999, the diversion canal was disconnected while the canal linking the lagoon with the industrial harbour was being extended.

From 1990, except for three interruptions from March 1991 to April 1992, from November 1994 to February 1995 and from November 1997 to April 1998, the trophic status of the lagoon was always kept under control. It was thus possible to monitor the course of the trophy after the waste was diverted.
This paper reports some fundamental data regarding the trophic status of the lagoon (nutrients, phytoplankton and phytobenthos) before and after the waste diversion (the cost of which was about 7 million Euros); the operation was designed to effect a decrease in the trophic level of the lagoon and enable fish production to be re-started.

\section{METHODS}

Samples were collected fortnightly at four stations (Fig. 1), always between 9 and 10 a.m. Samples were taken at the surface and near the bottom with a Niskin bottle. The samples for phytoplankton assessment were fixed in $4 \%$ neutralised formalin, while the samples to assess ammonium and nitrate nitrogen, reactive and total phosphorus, reactive silica and chlorophyll- $a$, was analysed according to Strickland \& Parsons (1968) and Scor-UNESCO (1966). Salinity, $\mathrm{pH}$ and temperature were also measured, using an Idronaut multiparameter probe. Phytoplankton was analysed following Utermöhl (1931). Phytobenthic biomass was assessed in 10 stations at various points in the lagoon (Fig. 1). In June 1994 and June 1998, the macrophytobenthic content present in $0.5 \mathrm{~m}^{2}$ squares was removed and its dry weight assessed after a two-hour desiccation at $110^{\circ} \mathrm{C}$. 
Tab. 1. Annual (a) and May-October (b) mean values of the analysed parameters during 1990-1998.

\begin{tabular}{|c|c|c|c|c|c|c|c|c|c|c|c|c|c|c|c|c|c|c|c|c|}
\hline & \multicolumn{2}{|c|}{$\begin{array}{c}\mathrm{T} \\
\left({ }^{\circ} \mathrm{C}\right) \\
\end{array}$} & \multicolumn{2}{|c|}{$\begin{array}{c}\text { Salinity } \\
(\%)\end{array}$} & \multicolumn{2}{|c|}{$\mathrm{pH}$} & \multicolumn{2}{|c|}{$\begin{array}{l}\text { N Ammon. } \\
\left(\mathrm{mg} \mathrm{N} \mathrm{m}^{-3}\right)\end{array}$} & \multicolumn{2}{|c|}{$\begin{array}{c}\text { N Nitrate } \\
\left(\mathrm{mg} \mathrm{N} \mathrm{m}^{-3}\right) \\
\end{array}$} & \multicolumn{2}{|c|}{$\begin{array}{l}\text { P Reactive } \\
\left(\mathrm{mg} \mathrm{P} \mathrm{m}^{-3}\right)\end{array}$} & \multicolumn{2}{|c|}{$\begin{array}{c}\text { P Total } \\
\left(\mathrm{mg} \mathrm{P} \mathrm{m}^{-3}\right) \\
\end{array}$} & \multicolumn{2}{|c|}{$\begin{array}{l}\text { Si Reactive } \\
\left(\mathrm{mg} \mathrm{Si} \mathrm{l}^{-1}\right)\end{array}$} & \multicolumn{2}{|c|}{$\begin{array}{c}\text { Chl- } a \\
\left(\mathrm{mg} \mathrm{m}^{-3}\right)\end{array}$} & \multicolumn{2}{|c|}{$\begin{array}{l}\text { Phyto t.d. } \\
\left(\text { cells } 10^{6} 1^{-1}\right)\end{array}$} \\
\hline & $\mathrm{a}$ & b & $\mathrm{a}$ & $\mathrm{b}$ & $\mathrm{a}$ & $\mathrm{b}$ & $\mathrm{a}$ & b & $\mathrm{a}$ & b & $\mathrm{a}$ & b & $\mathrm{a}$ & b & $\mathrm{a}$ & $\mathrm{b}$ & $\mathrm{a}$ & $\mathrm{b}$ & $\mathrm{a}$ & $\mathrm{b}$ \\
\hline 990 & 18.8 & 2 & .1 & 33.7 & 8.3 & 8.3 & 9 & 78.1 & 34.6 & 13 & 86.8 & 78.7 & 146.9 & 3 & 0.8 & 0 & 11.7 & 7.2 & 54.1 & .8 \\
\hline 14 & 21.1 & 22.9 & 5.3 & 26.6 & & 8 & 101.5 & 55.9 & 53.0 & 31 & 156.9 & 141.3 & .2 & & & 2. & 6.7 & 7. & & 0.5 \\
\hline & 19.0 & 24.3 & & 27.3 & & & & 74. & 38.0 & 21. & 106.8 & 107.6 & & & & & 8.5 & 13 & 0.0 & 9.8 \\
\hline 1994 & 20.2 & 24.9 & 25.8 & 25.1 & 8. & 8. & 43.8 & 28. & 6.9 & 2.3 & 79.3 & 91.4 & 232.2 & & & & 18.5 & 28 & 70.0 & 115.7 \\
\hline 1995 & 20.8 & 24.4 & 35.3 & 35.9 & 8. & 8.2 & 35.3 & 24.6 & 8.9 & 3.4 & 63.8 & 61.4 & 103.6 & 94 & 0. & 0. & 6.1 & 7.2 & 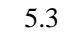 & 0.7 \\
\hline & 19.2 & 23.8 & 8 & 29.2 & & 8 & 134.6 & 31.6 & 43.8 & 9. & 103.5 & 70 & 15 & 11 & & & 10.9 & 15 & & 8.2 \\
\hline & 19.0 & 24. & & 3 & & & & 6 & & 8 & & 92 & & & & & 7.4 & 6 & & 2.7 \\
\hline 1998 & 20.1 & 23.9 & 35.3 & 36.1 & 8.3 & 8.3 & 34.0 & 28.2 & 15.7 & 11.2 & 58.6 & 72.2 & 120.2 & 135.0 & 2.0 & 2.0 & 16.6 & 20.4 & 10.5 & 12.4 \\
\hline . & 0.1 & 23.9 & 6.6 & 28.2 & 8. & 8.4 & & 59. & 33.1 & 17 & 107.4 & 104.8 & 18 & 20 & 3.0 & 3 & 1.3 & 14 & 132.8 & 32.7 \\
\hline 95/98 & 19.8 & 24.1 & 31.5 & 33.3 & 8.3 & 8.4 & 65.9 & 22.6 & 28.4 & 8.1 & 76.7 & 74.1 & 126.6 & 121.0 & 1.7 & 2.2 & 10.2 & 12.4 & 6.6 & 6.0 \\
\hline
\end{tabular}

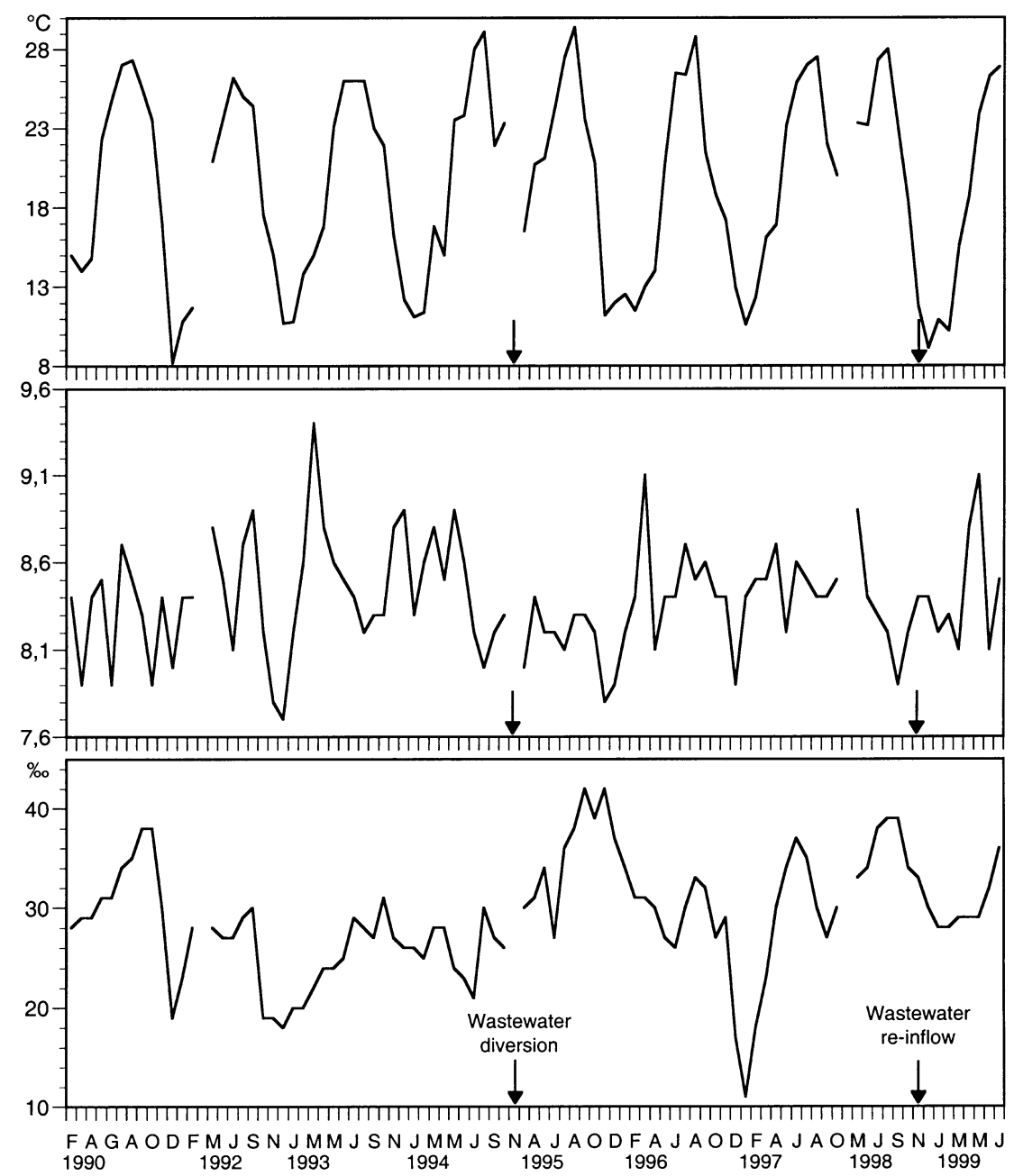

Fig. 2. Monthly mean values of temperature, salinity and pH during 1990-1999.

\section{RESULTS}

The annual mean values referring to the lagoon are reported in table 1; both annual and six-monthly (MayOctober) values are given, to make comparison easier. These six-monthly data are available for every year, both before (1990-1994) and after (1995-1998) the di- version, except for 1999 (the present year) that is concerned in the inflow of wastes due to the disconnection of the industrial canal for extension work.

Temperature (Tab. 1 and Fig. 2) showed seasonal variations, which always followed the same pattern, with summer maxima and winter minima. The lowest value $\left(8{ }^{\circ} \mathrm{C}\right)$ was recorded in December 1990 , with the 
highest values (above $29^{\circ} \mathrm{C}$ ) occurring during the summer months in 1994-1995-1996. The annual mean values before and after the diversion were identical, whereas the May-October averages were slightly higher $\left(0,6^{\circ} \mathrm{C}\right)$ in the latter period.

The seasonal variations of salinity (Tab. 1 and Fig. 2) were rather confused, though the lowest values were generally recorded during the winter months (the minimum was $11 \%$ in January 1997) and the highest during the summer months (maxima above $40 \%$ o between July and November 1995). Annual and six-monthly mean values revealed variations beginning from 1995, with values always higher than those of previous years, though not very different from those recorded in 1990. In general, salinity values before and after the diversion were rather different on both an annual (26.6\%o compared to $31.2 \%$ ) and a six-monthly (28.2\%o compared to $33.3 \%$ ) basis.

pH values (Tab. 1, Fig. 2) did not show clear seasonal variations. Oscillations were considerable during very close periods. However, values were quite high every year in spring (in relation to the development of phytobenthos), with a maximum of 9.4 (March 1994), and fairly low in autumn-winter, with a minimum of 7.7 (December 1992). Annual and six-monthly mean values showed no important variations except in 1995, the first year of the diversion, when the values were decidedly lower (about 8.2) than those of previous years (on average about 8.4) and also than those of subsequent years.

The mean monthly values of nitrate nitrogen (Tab. 1 and Fig. 3) ranged from $0-250 \mathrm{mg} \mathrm{N} \mathrm{m}^{-3}$; the highest values occurring in the winter wet period, in connection with continental freshwater inflows. The peaks were different from year to year, with a maximum in 1997. During the summer months, nitrate nitrogen fell nearly to zero. In 1994 and 1995, both annual and six-monthly mean values decreased sharply compared with those of previous years. During the following years, the annual averages returned to the values recorded in 1990-1993, whereas the six-monthly values (May-October) were lower than those recorded in 1990-1993, although they were slightly higher than those recorded in 1994-1995.

Ammonium nitrogen (Tab. 1 and Fig. 3) showed monthly mean values ranging from $0-550 \mathrm{mg} \mathrm{N} \mathrm{m}^{-3}$, with the highest values occurring in the winter wet period. The peaks were different from year to year, with a maximum in 1999. During the summer months, ammonium nitrogen fell to values lower than $50 \mathrm{mg} \mathrm{N} \mathrm{m}^{-3}$ and sometimes nearly to zero. Both annual and six-monthly mean values decreased markedly, as did those of nitrate, in 1994 and 1995 compared with previous years. In 1996, however, the annual averages increased, reaching values higher than those recorded in 1990-1993. In any case, seasonal averages kept the same values and had a further decrease in 1997.

Phosphorus showed a different picture from that of the nitrogen forms described above (Tab. 1, Fig. 3).
Both reactive and total phosphorus showed no seasonal variations; values fluctuated in an apparently random way. Values were always very high in both cases: reactive phosphorus about $100 \mathrm{mg} \mathrm{P} \mathrm{m}^{-3}$, with maxima above $250 \mathrm{mg} \mathrm{P} \mathrm{m}^{-3}$, and total phosphorus about $200 \mathrm{mg}$ $\mathrm{P} \mathrm{m}{ }^{-3}$, with maxima above $340 \mathrm{mg} \mathrm{P} \mathrm{m}^{-3}$. Reactive phosphorus never fell below $20 \mathrm{mg} \mathrm{P} \mathrm{m}^{-3}$, total phosphorus never below $40 \mathrm{mg} \mathrm{P} \mathrm{m}^{-3}$. However, the two forms displayed very different behaviour. The annual and six-monthly values of reactive phosphorus decreased progressively from 1992 to 1995 and, after an increase between 1996 and 1997, began to decrease again. In contrast, total phosphorus values increased progressively between 1990 and 1994; in 1995, there was a marked decline, with values dropping from about 230 to about $100 \mathrm{mg} \mathrm{P} \mathrm{m}^{-3}$. The values increased during the following years, but, except for 1999, to a lower level (about $120 \mathrm{mg} \mathrm{P} \mathrm{m}^{-3}$ ) than in the period 1992-1994 and compared with the data collected in 1990.

Reactive silica (Tab. 1 and Fig. 3) was in the range 0.3-13 $\mathrm{mg} \mathrm{Si}^{-1}$ without any apparent seasonal trend; the highest values were recorded between 1993 and 1995, the lowest in 1995 and 1990. Both annual and seasonal averages increased progressively between 1990 and 1994, rising from $0.8-0.5 \mathrm{mg} \mathrm{Si}^{-1}$ to $5.7-6.1 \mathrm{mg} \mathrm{Si} \mathrm{l}^{-1}$; after a drop in 1995, the values remained steady at about $2 \mathrm{mg} \mathrm{Si} \mathrm{l}^{-1}$.

Phytoplankton was described in terms of chlorophyll- $a$ and total density (Tab. 1, Fig. 4). Chlorophyll- $a$ showed considerable monthly variations, with high values and peaks sometimes above $30 \mathrm{mg} \mathrm{m}^{-3}$, with a maximum of about $70 \mathrm{mg} \mathrm{m}^{-3}$ in 1994 , generally during the spring and summer months. The year to year variations were also quite marked (the minimum value was $6.1 \mathrm{mg} \mathrm{m}^{-3}$ in 1995, the maximum $18.5 \mathrm{mg} \mathrm{m}^{-3}$ in 1994), as were the seasonal values (May-October), with a minimum of $6.3 \mathrm{mg} \mathrm{m}^{-3}$ in 1997 and a maximum of $28.7 \mathrm{mg}$ $\mathrm{m}^{-3}$ in 1994 . On the whole, the differences between annual $\left(0.9 \mathrm{mg} \mathrm{m}^{-3}\right)$ and seasonal $\left(2.8 \mathrm{mg} \mathrm{m}^{-3}\right)$ mean values before and after the diversion were very small. Total density had its highest values in $1990\left(454 \times 10^{6}\right.$ cells $^{-1}$ as annual mean) and 1994. The exceptional situation in 1990 was due to a bloom of ultraplanktonic Chlorella sp., which started soon after the dystrophic crisis in September 1989 and went on till February 1990. In the

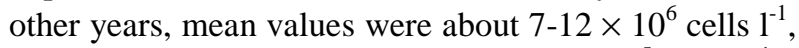

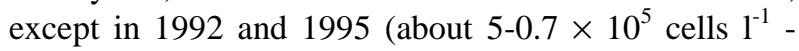
annual and May-October values, respectively) and in $1997\left(4.7-2.7 \times 10^{6}\right.$ cells $\left.1^{-1}\right)$. This suggests that there were no differences between the values collected before and after the diversion, except for the averages.

As very few data exist for phytobenthos, their importance can only be indicative; in 1994 and 1998, they indicated biomass values (average of the 10 stations) of $800 \mathrm{~g} \mathrm{~m}^{-2}$ and $750 \mathrm{~g} \mathrm{~m}^{-2}$, respectively. Species composition was characterised by the dominant presence (above 

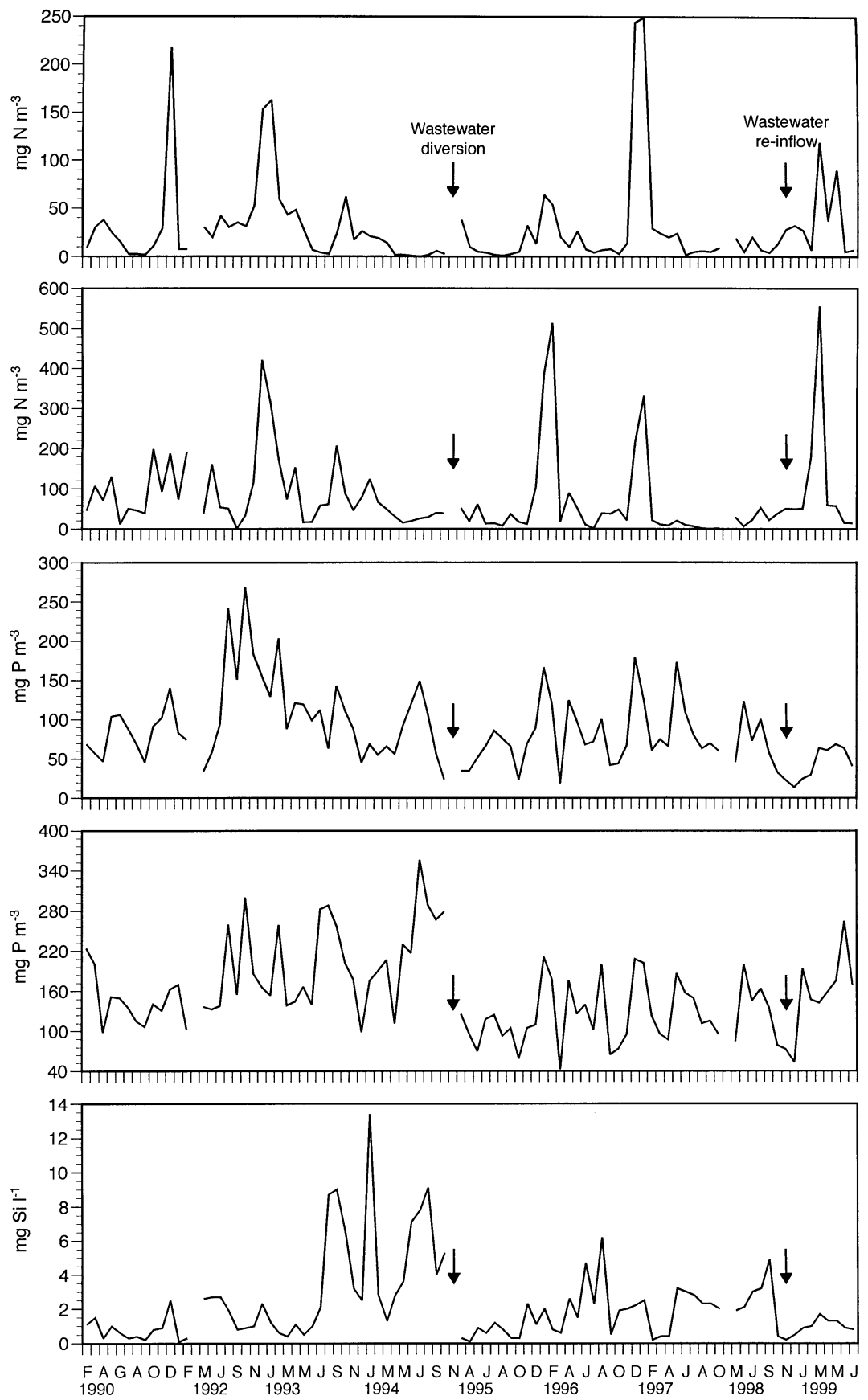

Fig. 3. Monthly mean values of nitrate nitrogen, ammonium nitrogen, reactive phosphorus, total phosphorus and reactive silica during 1990-1999.

95\%) of Ulva rigida C. Agardh and Chaetomorpha linum (Müll.) Kütz.

\section{DISCUSSION AND CONCLUSIONS}

The diversion of wastewater was designed to reduce the trophic level of the lagoon. However, an analysis of the data shows that this aim has not been achieved. The macrobenthic algae, which are the most important autotrophic component in the lagoon, and the phytoplank- tonic algae show that there have been no very clear variations. In 1995, when the diversion went into operation, some parameters showed situations which were very different from those of previous years, particularly as regarded salinity, phosphorus, nitrogen and silica. The increase in salinity (18\%) and the decrease in reactive silica (the May-October average was $35 \%$ and the annual average $45 \%$ lower than that of the following year) were probably related to the lower volume of 


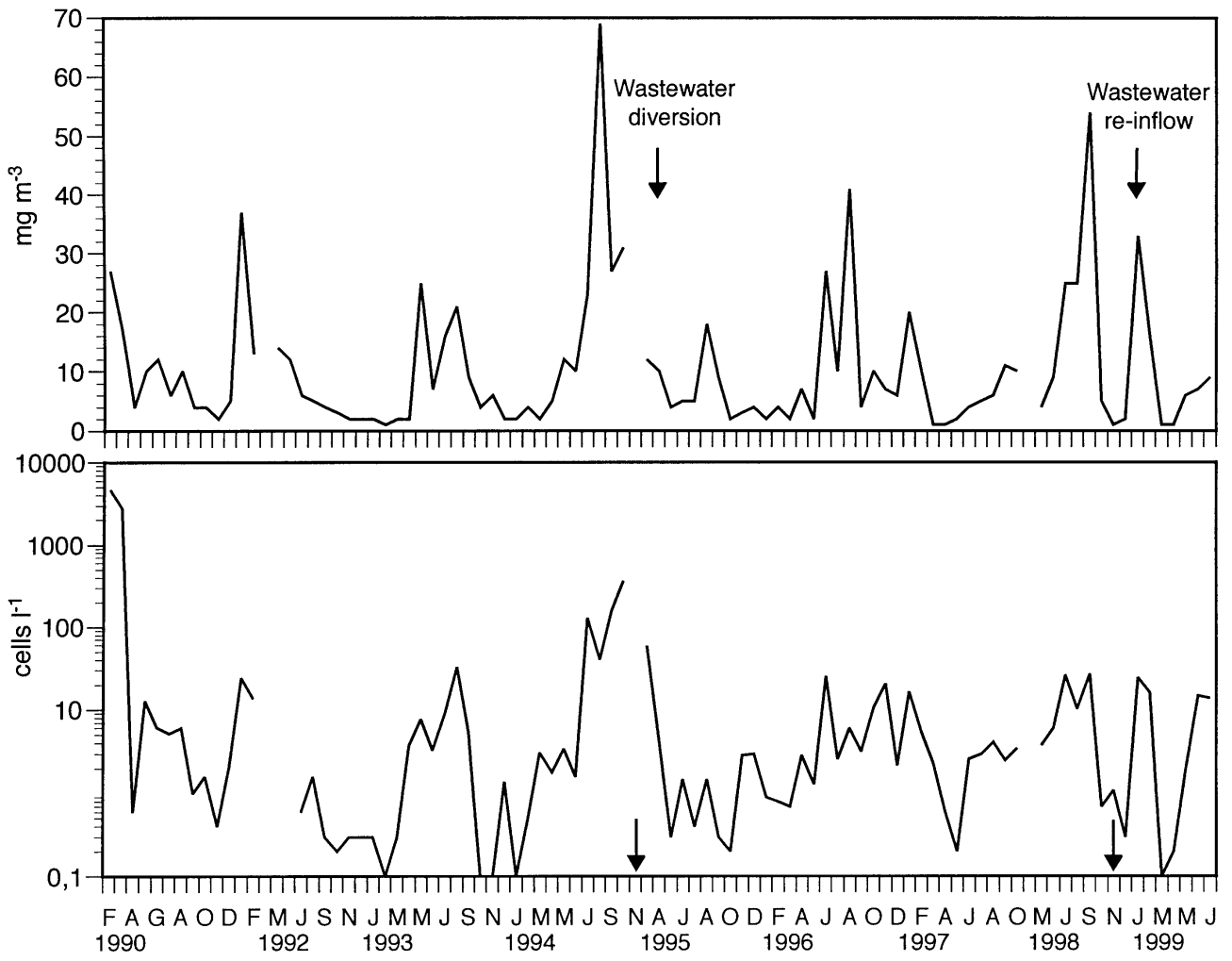

Fig. 4. Monthly mean values of chlorophyll- $a$ and total phytoplanktonic density during 1990-1999.

freshwater inflows, which were channelled directly into the industrial canal. This might have caused less dilution of the seawater and a reduction in the silica load carried to the lagoon. The loads of phosphorus and nitrogen carried to the lagoon also decreased. Both reactive and total phosphorus underwent a loss of about $30 \%$, in both averages, of $33 \%$ in the annual average and of $40 \%$ in the May-October average. Ammonium nitrogen showed a loss of $25 \%$ in annual mean values and of $62 \%$ in the six-monthly mean data, while for nitrate nitrogen there was a loss of $14 \%$ on an annual basis and of $53 \%$ on a six-monthly basis.

The high starting values, then, meant that the phosphorus and nitrogen decreases in the lagoon concentrations were proportionally actually quite low. Total phosphorus and inorganic nitrogen were constantly higher than $100 \mathrm{mg} \mathrm{P} \mathrm{m}^{-3}$ and $180 \mathrm{mg} \mathrm{N} \mathrm{m}^{-3}$, respectively, not sufficient to reduce algal development, to the extent that in 1997 and 1998 further dystrophic crises occurred. In 1997, these dystrophic episodes were due to a summer bloom of Cochlodinium polykrikoides Margalef, a planktonic species toxic for fish (Yuki \& Yoshimatsu 1989), which caused a total loss of fish production. The 1998 dystrophic episodes, which occurred only in summer, were due first to C. polykrikoides and then to Chattonella cf. marina (Subrahmanyan) Hara \& Chihara, and caused a partial loss of fish production.
It is difficult to explain these results. It is thought that, as can occur in lagoons with high macroalgal growth, phosphorus and nitrogen concentrations are highly affected by nutrient release from sediments, and also by the storage capacity of algae like Ulva. Moreover, the flux from sediments depends on a number of variables that are very difficult to consider together; for example, from iron concentration to organic matter accumulation and biodegradability, from precipitation of metal sulphide to several others (Barbanti et al. 1992; Viaroli et al. 1992a, 1992b, 1996; Bartoli et al. 1996; Stal et al. 1996). However, these aspects might be less important in the Santa Giusta Lagoon than they are in other lagoons with fewer exchanges with the sea, if we take into account the water exchange time of about a fortnight. In this case the theoretic renewal of the lagoon water should happen 24 times a year, making a total of about 100 times since the diversion. However, it must be pointed out that, owing to the considerable impact of the wind on the lagoon, a considerable re-suspension of particulate matter from the sediment often occurs, which might be one of the causes of the insufficient reaction to the diversion of sewage. The structure of the canal must also be very important, as is evident from the partial data collected in 1999. In fact, if the diversion system had operated correctly, these data would have shown traces of the water re-inflow from the diversion system, and some parameters such as nutrients would have 
increased, whereas others such as salinity would have decreased compared to 1995-1998. In contrast, Figures 3-11 show that all the parameters have a tendency to repeat trends and quantitative values without any particular variations compared with previous periods. Only ammonium nitrogen showed a considerable peak in March (above $500 \mathrm{mg} \mathrm{N} \mathrm{m}^{-3}$ ); at the same time, reactive phosphorus and reactive silica showed lower values from 1990 to 1998.

These data mean that, except in some months in 1995, the diversion system has stopped sewage inflows to the lagoon at best only to a limited degree. This agrees with the opinion of local fishermen that the canal is probably not impermeable and, consequently, water flows in and out of the lagoon through the containment barrier of the canal. Besides, the water in the diversion canal often does not flow into the industrial canal, because its level is frequently lower than that of the seawater, which should be stopped by floodgates. At pres??ent, a new pipeline is being built to improve the diversion system. This pipeline will intercept much of the wastewater that now flows into the diversion canal, carrying it directly to the sewage treatment plant from where, after treatment, it will be discharged directly into the sea.

\section{REFERENCES}

Barbanti, A., V.U. Ceccherelli, F. Frascari, G. Rosso \& G. Reggiani. 1992. Nutrient release from sediments and the role of bioturbation in the Goro Lagoon (Italy). In: R.A. Volleweider, R. Marchetti \& R. Viviani (Eds), Marine coastal eutrophication. Elsevier, New York: 475-487.

Bartoli, M., M. Cattadori, G. Giordani \& P. Viaroli. 1996. Benthic oxygen respiration, ammonium and phosphorus regeneration in surficial sediments of the Sacca di Goro (Northern Italy) and two French coastal lagoons: a comparative study. Hydrobiologia, 329: 143-159.

Cottiglia, M. 1981. Gli stagni salsi sardi, situazione attuale e possibilità future. Quad. Lab. Tecnol. Pesca, 61: 400-459.
Pugnetti, A., I. Ferrari \& A. Barbanti. 1989. Evoluzione stagionale dei parametri idrologici e della struttura dei popolamenti planctonici in una laguna del delta del Po (Sacca di Goro). Nova Thalassia, 10 Suppl. 1: 157-166.

Rossi, R. \& A. Cannas. 1992. Gli stagni sardi dalla pesca tradizionale all'uso di nuove tecnologie. Oebalia, 17(2): 110 .

SCOR working group 17. 1966. Determination of photosynthetic pigments in sea water. Unesco, Paris: $69 \mathrm{pp}$.

Sechi, N. 1982. Lo stato trofico di alcuni stagni salmastri costieri della Sardegna. Boll. Soc. Sarda Sci. Nat., 21: 285-295.

Sechi, N. 1983. Lo stato trofico e le condizioni ambientali dei laghi e degli stagni costieri della Sardegna. Mem. Soc. Geogr. Ital., 33: 373-383.

Stal, L.J., S.B. Behrens, M. Villbrandt, S. van Bergeijk \& F. Kruyning. 1996. The biogeochemistry of two eutrophic marine lagoons and its effect on microphytobenthic communities. Hydrobiologia, 329: 185-198.

Strickland, J.D.H. \& T.R. Parsons. 1968. A practical handbook of seawater analysis. Bull. Fish. Res. Board Can., 167. Ottawa: $310 \mathrm{pp}$.

Utermöhl, H. 1931. Neue Wege in der quantitativen Erfassung des Planktons (mit besonderer Berucksichtigung des U1traplanktons). Ver. int. Ver. theor. Angew. Limnol., 5: 567596.

Viaroli, P., A. Pugnetti \& I. Ferrari. 1992. Ulva rigida growth and decomposition processes and related effects on nitrogen and phosphorus cycles in a coastal lagoon (Sacca di Goro, Po River Delta). In: G. Colombo, I. Ferrari, V.U. Ceccherelli \& R. Rossi (Eds), Marine eutrophication and population dynamics. International Symposium Series. Olsen \& Olsen, Fredensborg: 77-84.

Viaroli, P., A. Pugnetti, M. Naldi \& V. Zaccaria. 1992a. Ricerche sul fitoplancton e su crescita e decomposizione di Ulva rigida nella Sacca di Goro. In: Sacca di Goro: studio integrato sull'ecologia. Franco Angeli (Ed.): 109-130.

Viaroli, P., M. Bartoli, C. Bondavalli, R.R. Christian, G. Giordani \& M. Naldi. 1996b. Macrophyte communities and their impact on benthic fluxes of oxygen, sulphide and nutrients in shallow eutrophic environments. Hydrobiologia, 329: 105-119.

Yuki, K. \& S. Yoshimatsu. 1989. Two fish-killing species of Cochlodinium from Harima Nada, Seto Inland Sea, Japan. In: T. Okaichi, D.M. Anderson \& T. Nemoto (Eds), Red tides: biology, environmental science, and toxycology. Elsevier, New York: 451-454. 